\title{
As(III) oxidation during full-scale aeration and rapid filtration
}

\author{
J.C.J. Gude, L.C. Rietveld \& D. van Halem \\ Department Water Management, Section Sanitary Engineering, Delft University of Technology, The Netherlands
}

\begin{abstract}
Arsenic (As) oxidation during full-scale aeration and rapid filtration was investigated. In the supernatant water, As(III) showed no apparent oxidation and meagre adsorption to HFO was observed. However, in the top of the filter bed rapid As(III) oxidation occurred and the subsequently formed As(V) was efficiently adsorbed. Although $\mathrm{MnO}_{2}$ could potentially oxidise As(III) it was found that As(III) oxidation was inhibited in the presence of $\mathrm{Mn}$ (II) and Fe(II). During ripening of virgin sand filters, As(III) oxidation was complete after 21 days of operation, before $\mathrm{Mn}(\mathrm{II})$ and $\mathrm{NH}_{4}^{+}$oxidation. Therefore, it may be concluded that formation of $\mathrm{MnO}_{2}$ could not have been responsible for As(III) oxidation, strongly suggesting that this is a microbial process. This process could develop amongst common groundwater bacteria and mineral precipitates, directly leading to an increased As removal in the filter bed.
\end{abstract}

\section{INTRODUCTION}

In the Netherlands, groundwater treatment commonly consists of aeration, with subsequent sand filtration without using chemical oxidants like chlorine. Oxidation of As(III) is imperative for efficient removal in this process (Bissen \& Frimmel, 2003; Gude et al., 2017), but the oxidation reaction between $\mathrm{As}(\mathrm{III})$ and $\mathrm{O}_{2}$ is sluggish and takes days (Kim \& Nriagu, 2000). However, As(III) oxidation was observed in the top layer of rapid sand filters without the use of chemicals (Gude et al., 2016). It was hypothesised that As(III) oxidation was caused by bacteria and/or $\mathrm{MnO}_{2}$. Both are present in the filter bed and could be capable of (catalysing) the oxidation reaction (Huang, 2014; Manning et al., 2002). However conclusive evidence whether bacteria and $\mathrm{MnO}_{2}$ are actually oxidising As(III) in rapid sand filters is scarce. For the purpose of identifying contributors to natural As(III) oxidation, jar tests with $\mathrm{MnO}_{2}$ grains and pilot plant research using sand filter columns were conducted.

\section{MATERIALS AND METHODS}

\section{$2.1 \mathrm{MnO}_{2}$ jar tests}

Jar tests experiments were executed in $1.8 \mathrm{~L}$, buffered, demineralised water. $20 \mu \mathrm{gL}^{-1} \mathrm{As}(\mathrm{III})$, $2 \mathrm{mg} \mathrm{L}^{-1} \mathrm{Fe}$ (II), $2 \mathrm{mg} \mathrm{L}^{-1} \mathrm{Fe}$ (III), $2 \mathrm{mg} \mathrm{L}^{-1} \mathrm{Mn}$ (II) and $100 \mathrm{mg} \mathrm{L}^{-1}$ pure $\mathrm{MnO}_{2}$ power were used to investigate $\mathrm{As}$ (III) redox and As sorption behaviour. The jars were constantly kept at $\mathrm{pH} 7$ and magnetically stirred. Samples were taken after 2, 5, 10, 20, 30, 60 and 120 minutes contact time. Sample preparation consisted of immediately filtering through $0.45 \mu \mathrm{m}$ and acidifying to $\mathrm{pH} 1$ until analysis by ICP-MS.

\subsection{Biological ripening experiment}

For this experiment 3 sand columns were loaded/ ripened with aerated, natural groundwater containing
Table 1. Water quality natural groundwater

\begin{tabular}{lll}
\hline Parameter & Unit & Value \\
\hline $\mathrm{As}$ & $\mu \mathrm{g} \mathrm{L}^{-1}$ & 13 \\
$\mathrm{Fe}$ & $\mathrm{mg} \mathrm{L}^{-1}$ & 1.4 \\
$\mathrm{Mn}$ & $\mathrm{mg} \mathrm{L}^{-1}$ & 0.04 \\
$\mathrm{PO}_{4}$ & $\mathrm{mg} \mathrm{L}^{-1}$ & 0.45 \\
$\mathrm{NH}_{4}$ & $\mathrm{mg} \mathrm{L}^{-1}$ & 0.62 \\
$\mathrm{pH}$ & & 7.54 \\
$\mathrm{HCO}_{3}$ & $\mathrm{mg} \mathrm{L}^{-1}$ & 246 \\
Temperature & ${ }^{\circ} \mathrm{C}$ & 12.4 \\
\hline
\end{tabular}

As(III) for 50 days. The remaining As in the filtrate was speciated to follow As(III) oxidation in the filter bed. Filtration rate was set to $1 \mathrm{~m} \mathrm{~h}^{-1}$ and supernatant level between 5 and $20 \mathrm{~cm}$. Principal water quality parameters are depicted in Table 1.

\section{RESULTS AND DISCUSSION}

\section{$3.1 \mathrm{MnO}_{2}$ jar tests}

In order to investigate whether $\mathrm{MnO}_{2}$ could be responsible for As(III) oxidation in the top of the filter bed, $\mathrm{As}(\mathrm{III})$ was exposed to $\mathrm{MnO}_{2}$ grains with possible competing substances: $\mathrm{Mn}$ (II) and $\mathrm{Fe}(\mathrm{II}) / \mathrm{Fe}(\mathrm{III})$. These results are depicted in Figure 1. Fig. 1 left shows $\mathrm{As}(\mathrm{III})$ in combination with $\mathrm{Fe}$ (II) only, Fe(II) and $\mathrm{MnO}_{2}$ and $\mathrm{Fe}(\mathrm{II})-\mathrm{MnO}_{2}-\mathrm{Mn}(\mathrm{II})$. The same experiments were executed for $\mathrm{Fe}(\mathrm{III})$ and are depicted in Fig. 1 right.

Fig. 1 left shows that As(III) removal is similar for $\mathrm{Fe}(\mathrm{II})$ with and without $\mathrm{MnO}_{2}$ grains with $\mathrm{As}(\mathrm{III})$ removal of $60 \%$ after $120 \mathrm{~min}$. On the other hand $\mathrm{Fe}(\mathrm{III})$ and $\mathrm{MnO}_{2}$ removed $98 \%$ of $\mathrm{As}(\mathrm{III})$ in $120 \mathrm{~min}$ (Fig. 1B). It was observed that the presence of $\mathrm{Fe}(\mathrm{II})$ and $\mathrm{Mn}(\mathrm{II})$ inhibited $\mathrm{As}(\mathrm{III})$ oxidation on $\mathrm{MnO}_{2}$. At $\mathrm{pH} 7, \mathrm{Fe}(\mathrm{II})$ and $\mathrm{Mn}$ (II) adsorption and oxidation were preferred over $\mathrm{As}(\mathrm{III})$ on the $\mathrm{MnO}_{2}$ surface. 

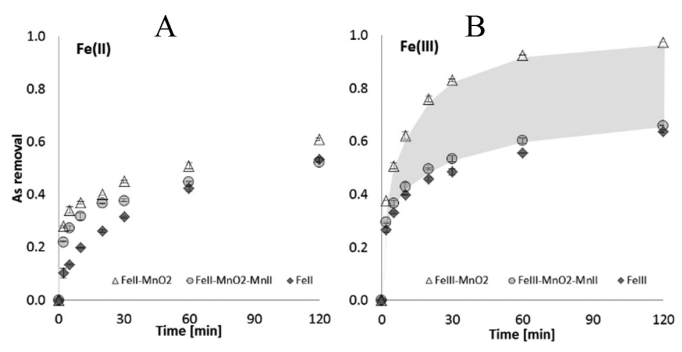

Figure 1. As(III) removal by $\mathrm{Fe}(\mathrm{II})$ and $\mathrm{Fe}(\mathrm{III})$ in presence and absence of $\mathrm{MnO}_{2}$ and $\mathrm{Mn}$ (II) at $\mathrm{pH} 7$ over $120 \mathrm{~min}$. Concentrations were $20 \mu \mathrm{g} \mathrm{L}^{-1} \mathrm{As}(\mathrm{III}), 2 \mathrm{mg} \mathrm{L}^{-1} \mathrm{Fe}, 2 \mathrm{mg} \mathrm{L}^{-1}$ $\mathrm{Mn}$ and $100 \mathrm{mg} \mathrm{L}^{-1} \mathrm{MnO}_{2}$ powder. (A) is As(III) removal by $\mathrm{Fe}(\mathrm{II})$ and (B) Fe(III) (Figure taken from Gude et al., 2017).

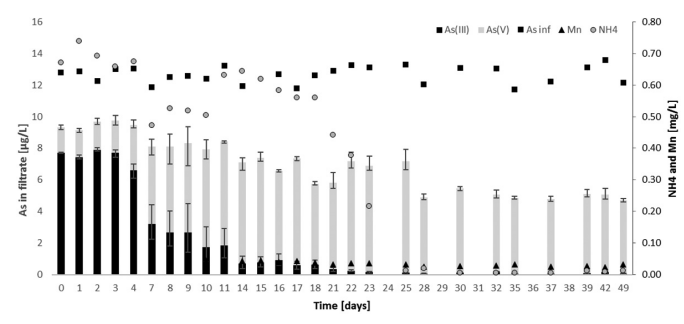

Figure 2. As(III) and $\mathrm{As}(\mathrm{V})$ in the filtrate of $\mathrm{As}(\mathrm{III})$ preloaded (top) and virgin sand columns (bottom) over time. Filtration velocity $1 \mathrm{~m} \mathrm{~h}^{-1}$ and bed height $0.5 \mathrm{~m}$. Initial concentration of the groundwater: $\mathrm{Fe} 1.4 \mathrm{mg} \mathrm{L}^{-1}$; As $13 \mu \mathrm{g} \mathrm{L}^{-1}$ (as As(III)) also depicted $<\mathbf{\square}>$; $\mathrm{PO}_{4} 0.45 \mathrm{mg} \mathrm{L}^{-1}$; $\mathrm{Mn} 0.04 \mathrm{mg} \mathrm{L}^{-1} ; \mathrm{NH}_{4} 0.62 \mathrm{mg} \mathrm{L}^{-1}$. As concentration in the filtrate is depicted as the sum of the As(III) and As(V) species.

However, unlike $\mathrm{Fe}(\mathrm{II})$, the addition of $\mathrm{Fe}(\mathrm{III})$ did not hinder $\mathrm{As}(\mathrm{III})$ oxidation on the $\mathrm{MnO}_{2}$ surface; resulting in subsequent effective $\mathrm{As}(\mathrm{V})$ removal by the flocculating hydrous ferric oxides. $\mathrm{Mn}$ (II) and $\mathrm{Fe}(\mathrm{II})$ are typically present in the pore volume of the top of the filter bed, therefore it can be concluded that just because $\mathrm{MnO}_{2}$ is present in a filter bed, it does not necessarily mean that $\mathrm{MnO}_{2}$ in the top of a sand filter is available to oxidise $\mathrm{As}(\mathrm{III})$.

\subsection{Biological As(III) oxidation}

Biological As(III) oxidation is a possible alternative for $\mathrm{MnO}_{2}$ to catalyse the aerobic oxidation reaction of $\mathrm{As}(\mathrm{III})$ and $\mathrm{O}_{2}$ in the top of the filter bed. This was investigated by ripening a sand filter with aerated natural groundwater water containing As(III) for 50 days. During rapid filtration of natural groundwater many biological processes take place, in this experiment it was tested whether As(III) present in low concentrations would be able to oxidise. Results shown in Figure 2 are averaged from triplicates and As in the filtrate is depicted as the sum of the As(III) and As(V) species.

As(III) was oxidized to As(V) gradually in the first 5 days $(10 \%)$ and showed a steep increase in the next 5 days $(>80 \%)$. This pattern follows a typical biological process where after a slow lag phase, a rapid log phase follows. $\mathrm{Mn}$ (II) removal was not observed within the 50 day experiment and $\mathrm{NH}_{4}^{+}$removal started after 15 days. Therefore it is concluded that independently of biological $\mathrm{NH}_{4}^{+}$and $\mathrm{Mn}$ oxidation processes biological As(III) occurred in the sand filter.

The oxidation of As(III) was accompanied by a slight increase in As removal. During the ripening of the virgin filter sand As(III) oxidation was complete after 21 days of operation, before $\mathrm{Mn}$ (II) and $\mathrm{NH}_{4}^{+}$ oxidation. Therefore, it may be concluded that formation of $\mathrm{MnO}_{2}$ could not have been responsible for As(III) oxidation, strongly suggesting that this is a microbial process.

\section{CONCLUSIONS}

As(III) oxidation in the top of the filter bed is crucial for efficient As removal in rapid sand filters. It was found with jar tests that the presence of $\mathrm{Fe}(\mathrm{II})$ and $\mathrm{Mn}$ (II) inhibited As(III) oxidation by $\mathrm{MnO}_{2}$. Therefore it is concluded that just because $\mathrm{MnO}_{2}$ is present in a filter bed, it does not necessarily mean that $\mathrm{MnO}_{2}$ will be available to oxidise As(III).

In addition it was found that the ripening of a virgin sand filter As(III) oxidation was complete before $\mathrm{Mn}(\mathrm{II})$ and $\mathrm{NH}_{4}^{+}$oxidation, strongly suggesting that As(III) oxidation is a microbial process. This process could develop amongst common groundwater bacteria and mineral precipitates, directly leading to an increased As removal in the filter bed.

\section{ACKNOWLEDGEMENTS}

This research is supported by the Dutch Technology Foundation STW, which is part of the Netherlands Organisation for Scientific Research (NWO), and which is partly funded by the Ministry of Economic Affairs.

\section{REFERENCES}

Bissen, M. \& Frimmel, F.H. 2003. Arsenic - a review. Part II: Oxidation of arsenic and its removal in water treatment. Acta Hydrochim. Hydrobiol. 31: 97-107.

Gude, J.C.J., Rietveld, L.C. \& van Halem, D. 2017. As(III) oxidation by $\mathrm{MnO}_{2}$ during groundwater treatment. Water Res. 11:41-51.

Gude, J.C.J., Rietveld, L.C. \& van Halem, D. 2016. Fate of low arsenic concentrations during full-scale aeration and rapid filtration. Water Res. 88: 566-574.

Huang, J.H. 2014. Impact of microorganisms on arsenic biogeochemistry: A review. Water. Air. Soil Pollut. 225(2): 1848.

Kim, M.J. \& Nriagu, J. 2000. Oxidation of arsenite in groundwater using ozone and oxygen. Sci. Total Environ. 247, 71-79.

Manning, B.A., Fendorf, S.E., Bostick, B. \& Suarez, D.L., 2002. Arsenic(III) oxidation and $\operatorname{arsenic}(\mathrm{V})$ adsorption reactions on synthetic birnessite. Environ. Sci. Technol. 36: 976-981. 